\title{
Estrogen and Progesterone hormone levels in Punganur Cattle
}

\author{
B.R.Naik., A.V.N.Siva Kumar*, K.V.Bramhaiah, A.Ravi and \\ V.Praveen Chakravarthi \\ College of Veterinary Science., Tirupati-A.P
}

\begin{abstract}
The present study was conducted at Livestock Research Station, Palamaner, Chittoor district, Andhra Pradesh to estimate female reproductive hormone values in Punganur cattle. The blood samples were collected from the twelve Punganur cows on 0, 3, 6, 9, 12, 15, 18 and 21 days of estrous cycle. The serum was separated from the blood samples and was transferred into sterile eppendorf tubes, labeled and stored in deep freeze $\left(-20^{\circ} \mathrm{C}\right)$ until hormonal assay for progesterone and estrogen was carried out. The estrogen level $(\mathrm{ng} / \mathrm{ml})$ in Punganur cows during estrus cycle was significantly higher $(P<0.01)$ on ' 0 ' day (20.24) and decreased upto $15^{\text {th }}$ days (12.36) and thereafter gradually increased to a level of 22.58 on day ' 00 '. The mean progesterone level $(\mathrm{ng} / \mathrm{ml})$ in Punganur cows during estrus cycle increased significantly $(P<0.01)$ upto $15^{\text {th }}$ day of estrus cycle and gradually decreased thereafter with the values ranging from 0.43 (' 0 ' day) to 10.66 (1 $15^{\text {th }}$ day) and from 8.64 (18 $8^{\text {th }}$ day) to 0.34 (day 00).
\end{abstract}

Key words: Punganur cow, estrus cycle and hormones

Indian subcontinent has a variety of indigenous breeds of cattle (Bos indicus) with wide genetic diversity. Most of these breeds are undergoing genetic degradation due to indiscriminate cross breeding and irregular mating among the breeds situated in each other's vicinity. As a result several indigenous breeds with many desirable traits are threatened with extinction while others are in the process of getting replaced completely by certain high producing crossbred animals. Punganur is one such breed of Indigenous cattle at the verge of extinction (Ramesha, 2001). Punganur, is the Worlds shortest, humped cattle with long tail with switch touching the ground, white and light grey in color with a broad forehead and short horns. The average height is 60-100 centimeters and weight 115-200 kgs. Indian breeds of cattle like Kankrej, Hariana, Gir, Deoni, Ongole, Redkhandari, Malvi, and Rathi (Mithuji et al., 1966 and Deshpande et al., 1987) reproductive hormone levels are available, where as Punganur cattle are poorly characterized both in terms of physiology and reproductively. Therefore there is a need to establish reproductive hormone levels to help conservation and propagation of these breed. Accordingly the present study was undertaken to establish the base line values of reproductive hormone levels in Punganur cattle.

\section{Materials And Methods}

The present investigation was conducted at Livestock Research Station (LRS), Palamaner, Chittoor district, Andhra Pradesh, India. The institute is located at an altitude of 2550 feet above mean sea level, at the longitude of $78^{\circ}$ and Latitude $13.15^{\circ}$ and mean environmental temperature, relative humidity and vapor pressure ranged between $12-40^{\circ} \mathrm{C}, 59-85 \%$ and $7-17 \mathrm{~mm} \mathrm{Hg}$, respectively.

A total of twelve (12) Punganur cows in estrus were selected from the Livestock Research Station. Estrus period in animals was detected by using teaser animal, the symptoms exhibited by the animals like vulval discharge, frequent urination, bellowing and also through rectal palpitation. All animals were maintained under uniform managemental and husbandry conditions. They were housed in well-ventilated asbestos roofed shed with cemented anti-slippery floor. The animals fed with concentrate mixture consisted of maize $40 \%$, wheat bran $37 \%$, ground nut cake $20 \%$, mineral mixture $2 \%$ and common salt $1 \%$ on dry matter basis and fresh greens and bhoosa were given ad libitum. The animals were provided with clean drinking water ad libitum twice a day at about 9.30 AM and 3.30 PM. The blood samples were collected from the jugular vein on 0, 3, 6, 9, 12, 15, 18 and 21 days of estrous cycle. The serum was separated from the blood and was transferred into sterile eppendorf tubes, labeled and stored in deep freeze $\left(-20^{\circ} \mathrm{C}\right)$ until hormonal assay for progesterone and estrogen was carried out. Estrogen and Progestrone hormone levels were estimated by ELISA method. The data was analyzed as per the Snedecor and Cohron., 1980.

\section{Results And Discussion}

Plasma estrogen and progesterone levels change continuously during estrous cycle and these changes bring about changes in the hypothalamo-pituitary-ovarian relationship that is the basis for endocrine regulation of reproductive cycles in mammalian females (Pineda and Dooley, 2003). The progesterone and estrogen concentrations during estrous cycle of Punganur cows are presented in Table 1 and Figure 1. 
The overall mean concentration of estrogen in the Punganur cows during estrous cycle on the day of estrus (day 0) and the day 3, 6, 9, 12,15, 18, 19, 20 of estrous cycle and subsequent estrus (day 00) were $20.24 \pm 1.17,11.26 \pm 1.17,14.25 \pm 1.17,10.53 \pm 1.17,15.24 \pm 1.17,12.36 \pm 1.17,17.83 \pm 1.17,20.28 \pm 1.17,21.47 \pm 1.17$ and $22.25 \pm 1.17 \mathrm{pg} / \mathrm{ml}$, respectively. Similar to the concentration of estrogen in the present study, Shukla et al., (2000) in crossbred cows, Lemon et al., (1974) in exotic cows, Gupta et al., (1998), Coe and Aldrich (1985), Jimenez (1988) and Selvaraju et al., (2002) also recorded same concentrations at different days of estrous cycle. But higher concentration of estrogen on different days of estrous cycle than the present finding were recorded by Mehrotra et al., (2005) in Holstein Friesian x Hariana cattle, Mutha Rao et al., (2005) in Ongole cows, Harpreet Singh et al., (2006) in Sahiwal crossbred heifers. While, the estrogen concentrations in the present study were higher than the reports of Agarwal et al., (1989) in cows, Purohit et al., (2000) and Venkatesan et al., (2005) in indigenous cows, Ecthernkamp and Hansel (1973), Christensen et al., (1974), Corah et al., (1974) and Glencross and Pope (1981) in exotic cows who recorded lower concentrations of estrogen on different days of estrous cycle compared to the concentration of estrogen in Punganur cattle. These inconsistencies in the concentration of estrogen hormone might be due to the differences in the sampling frequency, seasons and climate at the time of sampling and age and physiological stage (Lactating or not) of the animals (Alvarez et al., 2000).

The estrogen concentration showed a significant $(\mathrm{P}<0.01)$ decrease from day ' 0 ' to day 3 of estrous cycle which might be due to the ovulation and subsequent development of luteal tissue under the influence of luteinizing hormone (Hafez, 2008 and Noakes et al.,2001). Later, the concentration of estrogen from day 3 to day 6 showed a significant $(\mathrm{P}<0.05)$ increase but the concentration of estrogen did not reach the peak levels which indicated the development of first dominant follicle (Alvarez et al., 2000). Immediately after day ' 6 ' the concentration of estrogen decreased significantly indicating atresia of dominant follicle developed during first follicular wave (Hafez, 2008 and Noakes et al., 2001). Later, the concentration from day 9 onwards estrogen showed an increasing trend up to subsequent estrus day '00' at which time the concentration of estrogen was at peak level which might be due to the development of preovulatory follicle (Alveraz et al., 2000 and Hafez, 2008).

The overall mean concentration of progesterone in the Punganur cows during estrous cycle on the day of estrus (day 0 ) and day $3,6,9,12,15,18,19,20$ of estrous cycle and subsequent estrus day 0 were $0.43 \pm 0.89,1.89 \pm 0.89$, $5.39 \pm 0.89,6.24 \pm 0.89,9.72 \pm 0.89,10.67 \pm 0.89,8.64 \pm 0.89,5.22 \pm 0.89,1.67 \pm 0.89$ and $0.34 \pm 0.89 \mathrm{mg}$ per ml, respectively. The concentration of progesterone in the present study gained support from the findings of Mutha Rao et al., (2005), Harpreet Singh et al., (2006), Echterkamp and Hansel (1973) who also recorded similar concentrations of progesterone at different days of estrous cycle. But the concentrations of progesterone reported by Rabiee et al., (2002) at day ' 0 ' and Hamit et al., (2005) at different days of estrous cycle were higher than the present findings. While, progesterone concentrations in the present study were higher than the reports of Shukla et al., (2000), Mandal and Prakash (2003), Mehrotra et al., (2005), Venkatesan et al., (2005), Christensen et al., (1974), Dutta et al., (1989) and Selvaraju et al., (2002) who recorded lower concentrations of progesterone on different days of estrous cycle as compared to the concentration of progesterone in Punganur cattle.

The progesterone concentration showed significant increase from day ' 0 ' to day 15 . Later, from day 18 onwards, the progesterone concentration showed a significant decreasing trend and finally came down to the lowest concentration. This constant rise in the concentration up to day 18 might be due to the functional activity of corpus luteum and the decreasing trend from day 18 might be due to the initiation of luteolysis (Hafez, 2008).

Further, this study also recorded the lowest progesterone concentrations on the day of estrus and this gained support from the findings of all the authors who also recorded either similar or higher or lower concentrations on the other days of estrous cycle than the present study. These inconsistencies in the concentration of progesterone hormone might be due to the differences in the sampling frequency, seasons and climate at the time of sampling, age and physiological stage (lactating or non lactating) of the animals (Alvarez et al., 2000).

It is concluded from the study that the estrogen concentration showed a significant decrease from day ' 0 ' to day 10 with a significant rise on day 15 later there was an increase trend from day 15 to subsequent estrus day ' 00 '. Whereas the concentration of progesterone increased significantly from day ' 0 ' to day 15 , thereafter it decreased and the decrease was significant upto day 19 and insignificant from day 20 to subsequent estrus day '00'. Hence the trend of estrogen and progesterone hormones showed during estrous cycle of Punganur cow indicates the normal cyclicity of these breed like any other Indian cattle breed. 


\section{References}

[1]. Agarwal V K, Saini M S and Agarwal S .P. 1989. Serum estrogen and progesterone levels in repeat breeding cows. Indian Journal of Dairy Science 42: 373-374.

[2]. Alvarez P, Spicer L J, Chase C C, Payton Jr M E, Hamilton T D, Stewart R E, Hammond A C, Olson T A and Wettemann R P. 2000. Ovarian and endocrine characteristics during anestrous cycle in Angus, Brahman and Senepol cows in a subtropical environment. Journal of Animal Sciences 78:1291-1302.

[3]. Christensen P S, Hopwood Mh and Wiltbank J N. 1974. Levels of hormones in the serum of cycling beef cows. Journal of Animal Sciences 38: 577-583.

[4]. Coe B L and Aldrich R D. 1985. Relationship between endogenous estradiol-17ß and estrus behaviour in heifers. Journal of Animal Science 67: 1546-1551.

[5]. Corah L R, Alice P, Quealy, Dunn T G and Kaltenbach C C. 1974. Prepartum and post partum levels of progesterone and estradiol in beef Heifers fed two levels of energy. Journal of Animal Sciences 39: 380-385.

[6]. Deshpande S D, Sawant M K and Bapat T. 1987. Effect of age and sex on erythrocytic parameters in Red Kandhari cattle. Indian Journal of Animal Science 57: 590-91.

[7]. Dutta J C, Baruah R N, Leena Dutta and Talukdar S .C. 1989. Serum progesterone levels in repeat Breeding Jersey cows. Indian Journal of Animal Reproduction 10(1): 9-11.

[8]. Echternkamp S E and Hansel W. 1973. Concurrent changes in bovine plasma hormone levels prior to and during the first postpartum estrous cycle. Journal of Animal Sciences 37: 1362-1370.

[9]. Glencross R G and Pope G S. 1981. Concentration of estradiol $17 \beta$ and progesterone in the plasma of dairy heifers before and after cloprostenol induced and natural luteolysis and during early pregnancy. Animal Reproduction Science 4: 93-106.

[10]. Gupta A, Dabas Y P S, Lakhchaura B D and Mourya S N. 1998. Estradiol-17 B and progesterone profile in repeat breeding cattle. Indian Journal of Animal Reproduction 19(2): 126-128.

[11]. Hafez E S E 2008. Reproduction in Farm animals. $7^{\text {th }}$ Ed. Lea and Febiger. Philadelphia.

[12]. Harmit Yildiz, Erdal Kaygusuzoglu and Omer Kizil. 2005. Serum progesterone vitamin A, E, C and $\beta$-carotene levels in pregnant and non pregnant cows post mating. Journal of Animal and Veterinary Advances 4(3): 381-384.

[13]. Harpreet Sing, Luthra R A, Khar S K and Triloknanda. 2006. Estrous induction, plasma steroid hormone

a. profiles and fertility response after CIDR and ECG treatment in acyclic Sahiwal cows. Asian

[14]. Australian Journal of Animal Sciences 19(11): 1566-1573

[15]. Jimenez F, Galina C S, Duchteau A and Navarro-Fierro R .1988. Hevels of LH, Progesterone and estrodiol 17ß during natural and PGF-2 Alpha induced estrus in Indobrazil and Brown swiss cows in the tropics. Animal Reproduction Science 16: 199-206.

[16]. Mandal S and Prakash B S. 2003. Peripheral plasma progesterone concentration in relation to estrous expression in Sahiwal cows. Indian Journal of Pharmacology 47(1): 1-4.

[17]. Mehrotra S, Singh S K, Uma Shankar and Agarwal S K. 2005. Effect of certain indigenous medicinal plants on ovarian hormone profile and reproductive performance in anestrous cattle. Indian Journal of Animal Reproduction 26(1): 20-23.

[18]. Mithuji G F, Shukla P C and Patel B M. 1966. Haematological studies in Kankrej cattle. Indian Veterinary Journal. 43: 605-612.

[19]. Mutha Rao M, Uma Mahesh Y and Babu Rao K. 2005. Periovulatory steroid hormone profile in relation to superovulatory responses in native Ongole cows. Indian Journal Animal Reproduction 26(2): 87-90.

[20]. Noakes D E, Parkinson T J and England G C W. 2001. Arthur's Veterinary Reproduction and Obstetrics. $8^{\text {th }}$ Edition.

[21]. Pineda M H and Dooley M P. 2003. Veterinary endocrinology and reproduction. $5^{\text {th }}$ ed.

[22]. Purohit G N, Mahesh Datt, Sharma S S and Upadhyaya R C. 2000 .Estradiol prophile of rathi cattle during estrous cycle. Indian Journal of Animal Reproduction 21(1): 6-7

[23]. Rabiee A R, Macmillan K L, Schwarzen Berger F. 2002.Plasma, milk and fecal progesterone concentrations during the estrous cycle of lactating dairy cows with different milk yields 74: 121-131.

[24]. Ramesha K P 2001. Commissioned paper in the thematic working group on Domesticated Bio-Diversity, National Biodiversity Strategy and Action Plan, Ministry of Environment and Forestry, Government of India.

[25]. Selvaraju S, Agarwal S K, Karche S D, Srivastava S K, Majumdhar A C and Shankar U. 2002. Fertility response and hormonal profiles in repeat breeding cows treated with insulin. Animal Reproduction Science 73: 141-149.

[26]. Shukla S P, Sharma R D and Jindal R. 2000. Serum estradiol and progesterone levels during estrous cycle in repeat Breeding cross bred cows. Indian Journal of Animal Reproduction 21(2): 112-114.

[27]. Snedecor G W and Cochran W G 1994 Statistical methods. $8^{\text {th }}$ Edn Iowa State University Press, Ames, USA.

[28]. Selvaraju S, Agarwal S K, Karche S D, Srivastava S K, Majumdhar A C and Shankar U. 2002. Fertility response and hormonal profiles in repeat breeding cows treated with insulin. Animal Reproduction Science 73: 141-149.

[29]. Venkatesan P S, Shyam Shankar M and Subramaniam A .2005. Hormonal assay in repeat breeding cows and buffaloes. Indian Journal of Animal Reproduction 26(1): 66-68

Table 1:Estrogen and progesterone concentrations during estrous cycle of Punganur cows (ng/ml)

\begin{tabular}{|c|c|c|}
\hline Days & Estrogen & Progesterone \\
\hline 0 & $20.24 \pm 0.01^{\mathrm{ab}}$ & $0.43 \pm 0.01^{\mathrm{d}}$ \\
\hline 3 & $11.26 \pm 0.37^{\mathrm{ef}}$ & $1.83 \pm 0.37^{\mathrm{d}}$ \\
\hline 6 & $14.25 \pm 0.57^{\mathrm{de}}$ & $5.39 \pm 0.57^{\mathrm{c}}$ \\
\hline 9 & $10.53 \pm 0.82^{\mathrm{f}}$ & $6.24 \pm 0.84^{\mathrm{bc}}$ \\
\hline 12 & $15.23 \pm 1.54^{\mathrm{cd}}$ & $9.71 \pm 0.78^{\mathrm{a}}$ \\
\hline 15 & $12.36 \pm 1.16^{\mathrm{def}}$ & $10.66 \pm 2.24^{\mathrm{a}}$ \\
\hline 18 & $17.83 \pm 0.81^{\mathrm{bc}}$ & $8.64 \pm 0.86^{\mathrm{ab}}$ \\
\hline 19 & $20.28 \pm 1.79^{\mathrm{ab}}$ & $5.21 \pm 0.49^{\mathrm{c}}$ \\
\hline 20 & $21.47 \pm 1.38^{\mathrm{a}}$ & $1.67 \pm 0.28^{\mathrm{d}}$ \\
\hline Day 00 & $22.58 \pm 1.78^{\mathrm{a}}$ & $0.34 \pm 0.01^{\mathrm{d}}$ \\
\hline
\end{tabular}

Values with different superscripts in a column are significantly different $(\mathrm{P}<0.01)$

ANOVA (Estrogen) 


\begin{tabular}{|l|c|l|l|c|}
\hline \multicolumn{1}{|c|}{ Source } & $\begin{array}{c}\text { Degrees of } \\
\text { freedom }\end{array}$ & \multicolumn{1}{|c|}{ Mean squares } & F calculated & Significance \\
\hline Between days & 9 & 138.824 & 14.412 & $* *$ \\
\hline Error & 60 & 9.632 & & \\
\hline Total (SS) & 69 & 827.364 & & \\
\hline
\end{tabular}

S.Ed. $=1.658 \quad \mathrm{CD}(0.05)=3.3178$

ANOVA (Progesterone)

\begin{tabular}{|l|c|l|l|c|}
\hline \multicolumn{1}{|c|}{ Source } & $\begin{array}{c}\text { Degrees of } \\
\text { freedom }\end{array}$ & \multicolumn{1}{|c|}{ Mean squares } & F calculated & Significance \\
\hline Between days & 9 & 103.463 & 18.876 & $* *$ \\
\hline Error & 60 & 5.481 & & \\
\hline Total (SS) & 69 & 1260.050 & & \\
\hline
\end{tabular}

S.Ed. $=0.1 .251 \quad \mathrm{CD}(0.05)=2.5028$

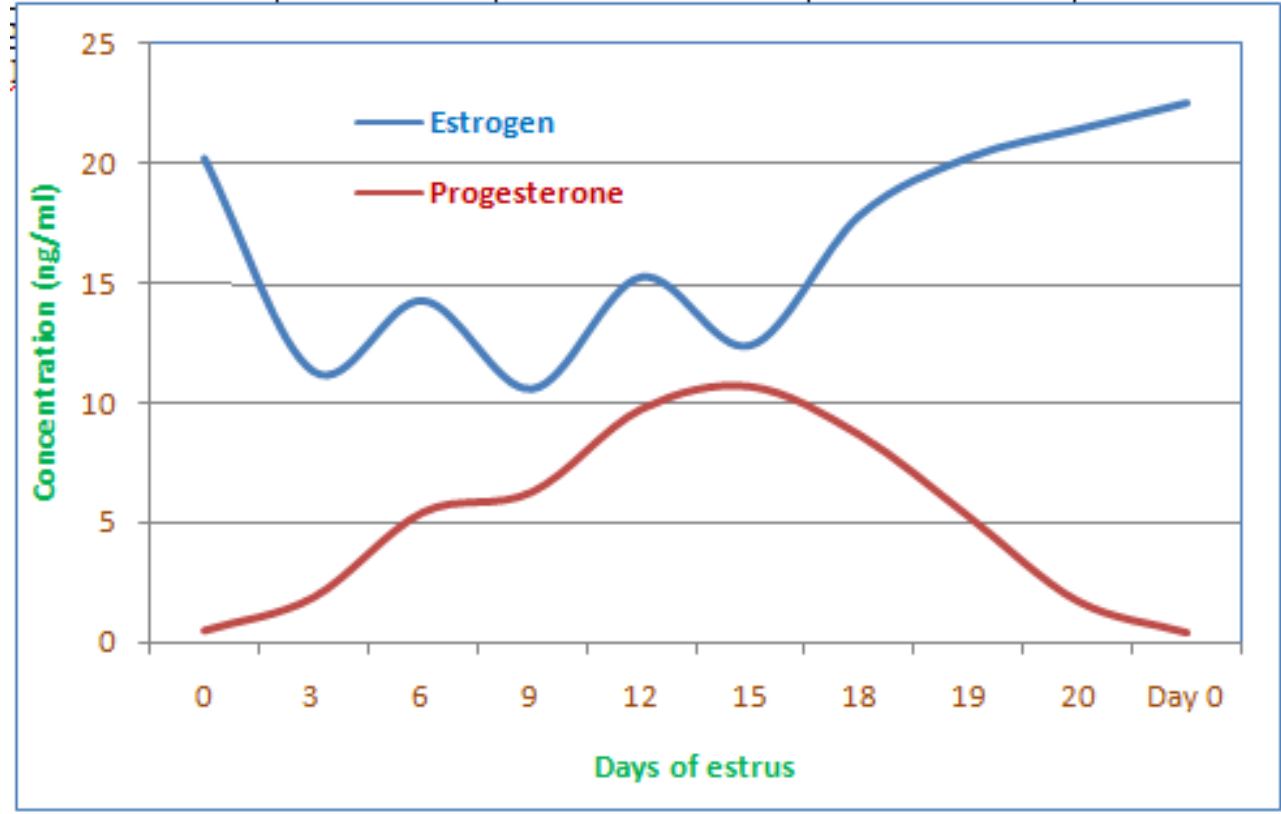

Fig. 1: Esterogen and progesterone concentrations (ng/ml) during estrous cycle of Punganur cow 